\title{
THE SIGNIFICANCE OF BAPTISM IN ESTONIAN FOLK BELIEF
}

\section{$\underline{\text { Ülo Valk }}$}

In Christian Europe baptism has traditionally occupied a central position in granting a child the right to live and accepting it into human society. It was not otherwise in Estonia. Though the ritual itself is short, lasting only a few minu-

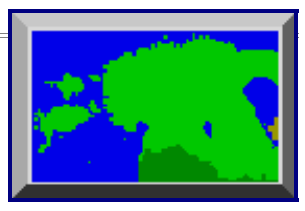
tes, it is of cardinal importance in shaping the fate of the child. The following is a short survey of how baptism has been interpreted in Estonian folk belief. Since baptism is closely connected with other issues such as choosing the name, specific features of the archaic rite of passage, relations between Christian and heathen features in Estonian folk belief, etc., these problems have also been dealt with. The article is to a great extent based on the collections of the Estonian Folklore Archives. Most of the beliefs analysed here were recorded between 1888 and 1940. (The abbreviation RKM refers to folklore recorded later.)

The rite of passage connected with the birth of a human being was naturally preceded by the selection of a name for the child. (About the concept of the rite of passage, see: Honko, 1964.) In Estonia this was mostly decided by father and mother, but advice could also be sought from godparents and close relatives. In Ludza it was the godparents who had a decisive say (ERA II 42, 501/3 (117-118)). In Setomaa the name could be determined by an Orthodox priest who sometimes consulted with the parents, giving them a number of variants to choose between (ERA II 173, 199 (51); RKM II 14, 178 (12)) This is a deviation from the general Orthodox tradition, according to which the parents have the right to select the name - but, of course, it must be a traditional Christian one. If it is the clergyman who chooses, he does so upon the request of the parents. Two strata can be distinguished in the principles of name-giving: the Christian and the heathen one, which continued parallelly with the Christian tradition.

The practice to name the firstborn child after its grandfather or grandmother is probably of preChristian origin. This is a widespread custom which has been observed in quite different cultural areas of Eurasia: in Finland, Karelia, Ingria, Germany, Sweden, Bulgaria, on the coast of the North Sea, in Ancient Greece, China, and no doubt in other places as well. This archaic international tradition bears evidence of the worship of ancestors and the belief that a human being is reborn in his/her posterity. Naming a child after grandparents is one of the few signs in Estonian folk belief that might be interpreted as a reflection of a former belief in the pre-existence of soul, of a conviction that a human being is not born simultaneously with the body, but rather reincarnates. (Evidence showing belief in a rebirth after death is considerably more numerous.) However, naming after grandparents cannot be interpreted as a certain proof of the belief into reincarnation, because we have no evidence of such a pre-condition in Estonia that in this case grandfather or grandmother had to be dead. According to some data, this was the case in Sweden, Bulgaria and in Judaic tradition, but the explanation here could be the fear that with giving away the name, the person's luck and health would also disappear and he/she might die. That it could still be a reflection of old Finno-Ugric ideas is suggested by the belief of the Khanty and Mansi that the soul of a dead relative reincarnates in the child. In several places the child was given a name only after it had been determined by divination, which of the relatives had taken rebirth (Karjalainen 1918: 39; 45-46). The idea that giving a child the name of an ancestor means reincarnation was also known among the Saami (Vilkuna 1959: 53). 
Only seldom have people in Estonia explained why they have given a child its grandparent's name: then the son would also be as good as he was (E $8^{\circ} 10,93(380)<$ Rõn); the child will be happy (E XII $28(157)<\mathrm{TMr})$; so it is better to remember one's dead relatives and to hold them in reverence (H I 4, 403 (1)); and that otherwise the child will die (ERA II 138, 530/1 (25) < Har). (The rest of reports found in the folklore collections of the Estonian Folklore Archives come from the following parishes: Jõe, Phl-2, Käi, Emm, Pär, Trm, Trt, Nõo, Räp). The following written record is an exception:

When there were only sons, the child was given his grandfather's name, then the next child would be a daughter; and vice versa (ERA II 254, $548(27)<$ Rei).

Often, parents gave their children their own name, the aims of which were much more obvious:

1) it ensures the child a long life (reports: Pär, Rõn, Ote-3, San-2, Vas).

If the first child is born to a young married couple, then it is baptised by the name of its parent. If it is a girl, then by her mother's name, if it is a boy, by the name of his father. Then the child will not die, so they say (H III 21, $682(16)<$ Ote).

2) By giving the child one's own name, people have consciously tried to limit the number of children (reports: Jür-2, LNg-2, Phl, Rei, Käi, Emm, Krj).

There is a custom that those who have many children and do not want any more of them give the last born child its father's name, then there will be no more babies (ERA II 201, 336 (24) $<\mathrm{Krj})$.

The same goal has evidently been kept in mind when people say that father or mother gives his/her name to the third (Noa, Kul) or the last child. In two cases, no explanation of the custom has been given (Ris, Kan).

According to a written record, there is a special meaning in giving the child its parent's name:

If there have been three successive children of the same sex in a family, that is sons, and if they wish to have a daughter, then the third son should be given his father's name, then a daughter can be expected. The same should be done when there are mostly daughters and they want to have a son, the third daughter should be given her mother's name. Then a son can be expected (ERA II 113, 235 (106) < Saa).

So mostly children have been named after close relatives, therefore the same names occur repeatedly from generation to generation. There is, however, a report stating the opposite:

The Christian name that the parents or grandparents have should not be given to a child, otherwise it will live an unhappy life (H II 58, 384 (7) < Pär).

According to a report from Tarvastu parish a girl got her name from her godmother and a boy from his godfather (ERA II 138, 150 (2). In Germany this was the usual practice. (See Simon 1991).

As we can see, by giving it a certain name, people sought to ensure that the child would not die, but live a long life. Mostly it was the name of the parent that was to guarantee this; according to a written report from Kaarma parish, the biblical names Adam (Aadam) and Eve (Eeva) also ensured the child a long life (H R 234 (219)). A similar belief was known among the inhabitants of Ludza and it evidently originates in the old Catholic tradition (e.g. in Poland these names are widespread; the same belief was also known among the Germans (Wuttke 1925: 387). There is a report where the following fact has been emphasised: 
One couple must not have two children of the same name; otherwise only one of them will be written down in Heaven (H IV 6, 588 (74) < Muh).

We consider it self-evident that each of the children of certain parents shall be given a different name, but it is not altogether impossible that with the parents seeking to ensure luck and long life to their children with the help of the most auspicious name, it has sometimes happened in Estonia that brothers and sisters have been namesakes. Such cases have occurred in Germany (Aly 1934/35: 953). In the Yaroslav Chronicles there is an entry dated 1644 about the children of a certain widow: "Big Ivashko went to Moscow to earn his living, the second Ivashko is 10 years old and the third Ivashko is 6." A family in Krakow had 11 sons, all of whom were called Jan (Krushelnitski 1986). In general, people avoided naming a child after its late brother or sister, which has been motivated as follows: otherwise the child dies (E XIII $281(57)<\mathrm{TMr}$, AES 23, 9 (63) < Ris); otherwise the dead cannot rest in peace ( $\mathrm{H} \mathrm{II} \mathrm{9,70}(50)<\mathrm{VNg}$ ); the child who has been given the name will have dreams about the dead namesake (E 57120 (3) < Ksi). There is a report from Ludza reading as follows:

$X$ named his first daughter Manka and she died. His 2nd daughter was also called Manka and she also died. And yet, the 3rd daughter was again called Manka, and she is alive (ERA II 42, $473(62))$.

The above-mentioned report illustrates especially clearly the relationship between a name and a person. Estonians, like many other peoples, believed that by naming the child after another person, his/her qualities, inclinations and temperament will also be transferred to the child:

The child shall be given the name of the most famous person of the family, so that the child would also become famous (E 80263 (3) < Hel).

If a child was given the name of a late relative, it indicated that the deceased had been highly respected (AES 23, $8(62)<$ Ris).

In Seto there has been the Christian tradition of choosing the name according to the day of birth of the child; the custom is widespread in Karelia, Ingria and other Orthodox areas. This meant, at the same time, that the child's fate was entrusted into the care of the particular saint. The Catholic church did not take the day of birth as a basis, therefore it did not necessarily coincide with the calendar name-day, because the day of baptism was considered much more important, as it was only then that a human being became a member of the congregation.

There are a few reports about celebrating one's name day which is also connected with Christian tradition and the worship of saints.

In olden times you had to be content with the name given to you. Depending on the time when the child was born, which holiday was approaching, the priest mentioned three names and one of them had to be given. If there was "praasnik" (holiday), then he who had such a name went to church to celebrate the name day. It was said to be good if you could go to church on your name day. Then God would help you everywhere (ERA II 173, $199(51)<\mathrm{Se})$.

According to the customs of the old, children are named after the saints' days: if a boy is born before St. Michael's, St. Martin's, St. Thomas', St. Andrew's, St. George's, St. John's, St. Bartholomew's Day, he is given that name whose day is approaching, so that the child will have patience - and to make it easier to remember one's birthday without the calendar date (H I 4, 403 (1)). 
On the morning of St. Mary's Day people tried to tie feet of the girls named Mari in secret, and they would not let them go until Mari had given them "Mary's blush" (red wine). If they could not tie a girl called Mari in secret, while she was asleep, then boys would tie her feet by force. Girls with the name Mari always tried to have a bottle of red wine ready then, otherwise they would not be released (RKM II 101, 322/3 (3) $<$ Hää $<$ Mih).

It is, however, no wonder that there are comparatively few reports of name-days in Estonia. When Estonians were christened in the 13th century, the Catholic church did not introduce obligatory Christian names and these became dominant only at the end of the 15th century (Palli 1961: 116); shortly afterwards followed the Reformation that abrogated the worship of saints. So, the relationship between Christian names and saints could in no way be deeply rooted in the people's traditions; the Orthodox Setomaa district is an exception.

It is to be emphasised that the earlier custom of giving a name after relatives and the Christian custom of giving a saint's name are quite close as to their content. In both cases there is a clear connection between the person who is given the name and the one who had it earlier. The name is like a connecting joint linking a person to the mythological world that protects him: to the Heavenly Kingdom (in case of the saint's name) and to the world beyond (in case of the ancestor's name). In case of very distant past, one might perhaps sometimes talk about a person's connection with his/her totem.

It is not quite clear what was the transition ritual of name-giving in pre-Christian Estonia like, and therefore we are going to concentrate on a later stratum that bears in itself some very old features. Clerical christening and its celebration (baptism, christening and the attendant festivities) have exercised a strong influence on the popular tradition, modifying it to a greater extent than Christian wedding or funeral ceremonies ever did. (It is with these three events that the three basic rites of passage in the Estonian popular tradition are connected, i.e. passage from one social status into another.) Here we can draw a conclusion that among heathen Estonians the social recognition of a child was not connected with a ritual so regulated and elaborate as in the case of wedding or funeral, the archaic features of which have been preserved much better. That it was no less important, however, is confirmed by the fact that this, also, was celebrated for several days.

At this point, the relationship between baptism and name-giving has to be explained. Baptism cannot be identified with name-giving - it is a Christian ceremony, a sacrament, the content of which is ritual purification of the original sin and admission of a person into the Christian congregation, which also meant recognition of a new-born baby as a member of the community. It became associated with name-giving, because in the process of baptising it is customary to call the child by name and to record the name in the parish register. Sometimes the child could be left with no name at all after baptism. For example, according to the Lutheran agenda from the period of Swedish rule, if christening takes place without the parson, he must ask the baptiser whether the child has got a name. If not, then the child is given a name only when christening is registered by the parson (Kässi-ramat 1699). Ludwig Dunte (1597-1639), a pastor in Tallinn, also discusses in his Lutheran manual, whether children who are not given a name during emergency baptism should be christened anew. His answer is negative. ("Demnach ist zu antworten/ dass das Kind nicht wieder zu tauffen/ denn ob schon der Nahme der Tauffe gar nahe anhengt/ so höret er doch nicht in priori zu der substantz." (Dunte 1643: 630)).

So there is a magical side in baptism that is much more important than the name-giving. This act was understood as putting a person under heavenly protection, which prevented evil forces from attacking him. The following folk legend bears evidence to that: 
A herd-boy was taken into a household. His parents were dead. At night the herd-boy slept on the stove, but often he cried that someone was attacking him in the form of a toad-like creature. Then the family thought that he might not be baptised. At once, they summoned the neighbouring family and the child was baptised. From then on, the attacker disappeared (ERA II 58, 45 (3) < Vän (1933)).

Only after baptism could the child's name be uttered: it had been chosen earlier, but kept secret to prevent inimical forces from attacking the helpless child. This is evidently the explanation to the prohibition, of which there are but a few reports and which people in later times could not explain.

A child's name must not be uttered before baptism (H II 47, $294(55)<$ Saa).

A child's name must not be said until early in the morning when they set out to church (ERA II 29, 770 (6) < Käi).

Risti parish, 1921 - there is still a custom here that before christening the child must not be called by name. If this is done, the child will be a thief when it grows up (Saareste 1921: 425).

So, the name itself did not increase a person's spiritual power, it was rather like an external sign marking that the rite of passage had taken place which increased the child's power and which was accompanied by the revelation and registration of the name.

According to the observations of some scholars, there are a great number of folk narratives connected with the rites of passage, because these are critical periods for a human being when he/she is threatened by various supernatural forces (see, e.g., Lindow 1978). In Europe, stories about various mythological creatures and wizards who tend to steal or change not yet baptised babies enjoy great popularity. In Estonia this motif is primarily related with the devil (Aarne 1918, Sagen No. 19-23). The stories about the Evil One changing children have a mythological background that is very much alive and even today: various methods are known to avoid this misfortune. A noteworthy fact that is stated repeatedly is that it is the unbaptised (and not nameless) children who are threatened.

The Evil One changes children, if the Lord's Prayer is not said immediately. Miserable and wretched people have been changed by the Evil One. They were called 'piru' - a changed child. A child must not be left alone, otherwise they say that the Evil One would change it. When the Word of God has gone over the baby, then he won't change any more. It may well be that some people have been changed, some people are ugly, they do not learn to talk or walk. Even today there are people like that (ERA II 37, 255/6 (47) < Jõh).

If an unbaptised child is left alone in a room, then a knife must be placed nearby, otherwise the Evil One may exchange it for his own child (IIl 19, $716(20)<\mathrm{Vil}<\mathrm{Hls}$ ).

An unbaptised child must not be left alone, otherwise the devil comes and takes the child away. When I was washing clothes, I always put a string through the door-hole, the other end fastened to the cradle. I did not dare to leave my baby alone. When I went to the farm to pull flax, I always took my child with me. The others scolded, You must be nuts, taking your unbaptised baby out to the field. But I did not dare to leave it behind, who knows what could have happened (ERA II 124, 282/3 (3) < Saa).

In some places, the devil stole children, so that he himself could take their place and be baptised instead of the child, thus getting strong (ERA II 9, $164(3)<$ Emm). 
An unbaptised child must not be left alone - not even for a moment: the devil changes the child. Therefore, baptism must take place according to the practices of the church, otherwise it has no power (ERA II 40, $207(2)<\mathrm{Vlg}<\mathrm{Vi}$ ).

The last two reports are of particular interest, because they manifest the belief that baptism really has the effect of strengthening a human being. Oskar Loorits stresses that the motif of changing children has been borrowed into Estonian popular tradition from the Germanic peoples and it bears entirely German-Swedish traits. In most parishes, there is no special word for an exchanged child: people call them devil's child or exchanged child (Loorits 1949: 232-233).

This is an extremely interesting motif in the sense that it offers an actual opportunity to observe the influence of Christianity on Estonian folk beliefs, because here this influence is clearly visible.

Namely, there is a belief in Christianity that it is only baptism that liberates a human being from the devil's power, and though its interpretation has become rather symbolic, there is no doubt that in the Middle Ages the devil was indeed considered an empirical demonic being. In Martin Luther's Catechism this idea has been expressed in the following way:

"Mis annab ehk sadab ristiminne? Temma sadab pattude andeks andmist, peästab ärra surmast ja kurratist ja annab iggawesse önnistusse keikille, kes seda ussuwad, mis Jummala sanna ja tootussed kulutawad"

('What does baptism give or grant us? It gives us absolution, saves us from death and devil and grants an eternal blessing to everyone who has faith in the Word of God and His

Promises.' (Eesti-Ma-Rahwa Koddo- ja Kirko-Ramat 1793. The quotations in Estonian have been chosen deliberately from earlier translations, as these are, among other things, of linguistic interest.)

A summary of Martin Luther's teachings about baptism can be found in his book Taufbüchlein verdeutscht, aufs neue zugericht (1526), according to which, after the Catholic tradition, the act of baptism must be preceded by exorcism - driving away evil forces from a sinner (Lat. exorcismus) that is carried out through the magic power of ritual and word and that takes place outside the church or in the vestibule (Realencyclopädie 1907). In earlier periods, the emphasis in Christianity was laid on the renunciation of Satan (Lat. abrenuntiatio satanae) and exorcism, because it was the conviction that the spirit of God could have no place where there was Satan with the demons; and vice versa. This magical preventive power was also believed to be contained in uttering the name of Jesus (Heitmüller 1903).

As the mediaeval Catholic tradition was uniform all over Europe, the formula of exorcism in Estonia was probably not much different from that elsewhere, sounding as follows:

Exorcizo te, immunde spiritus, in nomine Patris, Filii et Spiritus Sancti, ut exeas et recedas ab hoc famulo Dei N... (here the name of the person to be baptised is uttered).

In Lutheran church, the same formula was said in Estonian:

Minna wannotan sind erra / sa rojane Waim / Jummala se Issa / Poja nink pühha Waimo nimmel / et sa erra tagganet sesinnasest Jesusse Christusse sulasest (ümmerdajast) Amen. ('I exorcise you, you foul spirit, in the name of Father, Son and Holy Spirit, that you withdraw from this servant of Jesus Christ, Amen.' Kässi-ramat 1699). 
But the motif of saving human beings from the devil can be found in a number of other religious texts. E.g.:

"Üks Tennämine pühha Ristmisse eest, nink üks Palwus wastse Ello perräst. [---] Minna olle Kristust henne päle tömbnu, sis om nüüd temmä Surm minno Ello, temma Öigus minno Wägi; et mulle nü̈d, kunna ma Kristusse sissen olle, Pat, Surm, Kurrat, Pörgo-Haud nink Ilm ei woi Kahjo tetta" ('Thanksgiving for the Holy Baptism and Prayer for a New Life. [---] I have drawn Christ upon myself, and now His death is my life, His right is my might; and now as I am in Christ, no Sin, Death, Devil, Hell or World shall harm me.' Lühhikene Tarto-Ma-Kele Palwuse Ramat 1790)

Even today the motif of the devil's power before christening survives in Lutheran religious literature. I shall illustrate it with two quotations from baptismal hymns:

Kuradist oh tagane, Sest sa oled temast lahti;

Ära käi ta järele, Muidu on see seadus katki; Wõitle Wapralt tema wastu, Jeesu jälgi mööda astu. [---]

See wesi patust puhastab, Teeb kuradist meid lahti,

Ta iluga meid ehitab, ja annab meile mahti,

Et wangipõlvest peaseme, Ja Isa lapsiks sünnime, Ja pärime ta riigi.
(Oh renounce the devil, because you have got rid of him.

Do not follow him, lest this law should be broken.

Fight him bravely, and follow the steps of Jesus. [---]')

This water purifies our sins, and rids us from the devil

It adorns us with beauty and gives us power

To be free from bondage and be born as Father's children and inherit His Kingdom.')

(Uus Lauluraamat 1901: No. 316; 321).

The exorcism that accompanies baptism has survived in the clerical practices up to this day, at least in verbal form. So, before baptising an apostolic Orthodox priest prays to God with the following words: "Give him an angel of light to accompany him for the whole of his life, to protect him from persecution and evil thoughts. Drive out from him the spirit of deceit, the spirit of lies and foulness, and the spirit of any kind of idolatry (Talitusraamat 1940: 13-14). In the Agenda used in the Lutheran Church of Estonia, it has been said: "This holy and blissful faith puts everybody who is baptised into it under the obligation to renounce Satan and his ways and works and to serve only the triune God and to live for Him." (Agenda 1951: 277)

This Christian background helps to understand how the word vanapagan ('Old Heathen') appeared in the Estonian language among the numerous euphemisms and synonyms for the devil. It is not quite clear whether the word pagan was borrowed from Latin or Old Russian, but as far as the semantic change is concerned, this is not so important, because at the time of borrowing the meanings in both languages coincided (Vasmer 1987: 294; see also Viires 1989). The basis for the semantic change in the Estonian language (unbaptised person $=>$ devil) could be the following reasoning: (a) until baptism the child is a heathen and under the devil's power; (b) if Satan's power is not broken through baptism and the person remains a heathen, the devil's power increases 
constantly; (c) such a person eventually merges into the devil, at the same time acquiring mythological qualities. It goes without saying that before the 20th century an unbaptised person was a rare exception in Estonia and that such a heathenish status applied, above all, for Jews and, to a lesser extent, for Gypsies. It is noteworthy that both of these ethnonyms have had a slightly negative connotation in the vernacular; they have been used as invectives and served as bases of euphemisms for the devil and pedagogical ficts.

So, the protection of the child in the present life was one of the reasons why baptism was an urgent matter, but on the other hand, it was also caused by fear that the child might die as a heathen. Namely, according to mediaeval tradition an unbaptised child could not go to heaven but remained in an indefinite sphere somewhere between the hell and the purgatory (limbus infantium) and it was not buried in the holy ground of the cemetery. (The first circle of the hell where unbaptised children and virtuous heathens are appointed has been described by Dante in his Inferno, Cantus IV).

The Estonian folk tradition has maintained several ideas and customs connected with the death of an unbaptised child. People remember that they were buried in the churchyard, but without a cross (AES 23, $9<$ Ris); or in unhallowed ground (E $83540(19)<$ Var); they believed that such a child's soul would fall into the hands of evil spirits (AES 23, $9<$ Ris); to the Evil One (ERA II 63, 79 (175) $<$ Põl); "into the dark world" (E, StK 28, 275 (93) < Lut); or to hell (ERA II 125, 63/4 (114) < Vai). There is an exceptional report from the parish of Koeru that states that such a child will be baptised in heaven (H II 67, 382 (15)). In Ludza, a child who had died without being baptised was not shown even to one's own family and the whole thing was hushed up (ERA II 42, 477 (71)). In Estonia the old Christian idea has been expressed in the following text:

Children who die in birth or before christening will be given neither roses nor toys in Heaven, they have to play with their own fingers (ERA II 129, 409 (2) < Mär).

The child dying without being baptised is considered an unlucky and dangerous thing, because it will not go to the "place" where the baptised are. And also, the child complains to God, why its parents have been so "careless". Now it must be isolated from the others and cannot be in their company where it would have been as "joyous" as the others. Therefore a child is baptised as soon as possible. A child is not kept unbaptised over two or three weeks. And if an "illness" should appear, the child will be baptised immediately when the godparents have been summoned. It may even happen on the same day when the child is born (H I 1, 105 $(1)<\mathrm{Kad})$.

[---] In Vigala the child was baptised after only a few days, usually on the next Sunday after its birth. A child was not kept unbaptised for a long time: people feared that it might fall ill and die. Until baptism there was light in the chamber every night. Pine splinters were burned; somebody had to sit all night with a fire steel and light splinters. In several places a hymnal was placed into the baby's mother's bed, naturally to prevent the Evil One from changing the child. People were very much afraid that the child might die unbaptised. They thought that an unbaptised child would complain to God about its parents. Also, an unbaptised child cannot get into the place where the baptised children go when they die (E III $8(38)<$ Vig).

Abandoning a child between birth and the rite of passage, when it is given a social status, was not considered a crime, and it seems that a change was brought in by the infiltration in Christian ideas (Pentikäinen 1969: 100-101). Earlier it was the usual practice in the Nordic countries to abandon an unwanted child. An Icelandic saga from the beginning of the millennium states: "There was a 
custom, when the country was still pagan, that those who were poor and who had many children to care for, allowed their children to be abandoned; and this was always regarded as an evil deed." (Gunnlaugs saga ormstungu; Pentikäinen 1968: 69).

Abandoning a child who had been given a name was considered a murder in pre-Christian times. According to the saga tradition, name was the most important criterion that secured the child's recognition as a member of the community. But the name-giving was preceded by another symbolic act with which the mother recognised the child as her own: she took the child to her breast for the first time (Pentikäinen 1968: 74-75).

In the Old Norse law-book that was valid until 1274 it reads: "Concerning a hairy child. If a child is born covered with hair and it has no human head and no human voice, then it must be taken into the church, if so desired and the priest should be allowed to baptize it if he wants and a grave should be dug in the churchyard and the child put there and a gravestone on top, carefully so that dogs or ravens cannot get there. And let no earth be dropped (into the grave) before the child has died, and let it live as long as it is able!" (Pentikäinen 1968: 80).

Another Norse Christian law-book of the same period says: " The women of the house and neighbourhood must be present at the bedside of the woman who has given birth to a child and let them not go from there before they have put the child on the mother's breast. And if the child is dead when the people come a second time to the mother and if they then see marks of a hand or cord, if the child has been strangled or suffocated and she (the mother) speaks and is conscious then the mother must be her child's killer. Let her then forfeit all her property and peace in the country and all her chattels. Let her go to a pagan land and never come to those who are Christian people. Because the murder of a pagan is worse than the murder of a Christian, because the soul of the man who dies a pagan is destroyed. And if she is delirious when people come to her, then let her go and confess to a priest and let her not pay a fine." (Pentikäinen 1968: 84-85).

Abandoning a child has also been touched upon in old Balto-Finnic folk songs, several of which have been transmitted over the boundaries of languages ("Maret's child", "Useless education"); the archaic origin of such songs is confirmed by an analogical song of the Latvians (Kuusi 1963, 146147). Thanks to Elias Lönnrot's Kalevala, the most famous of such songs is "Väinämöinen's Judgement", which occupies the central point in the last, 50th runo, and reflects the triumph of the Christian ideas among Nordic heathens. A North Karelian variant of this song type includes the following passage:

\begin{tabular}{|c|c|}
\hline [---] & [---] \\
\hline Poika synty Mar & Mariat \\
\hline Ei tietä isoa sillä: & of whom no father was known: \\
\hline isä kutsu Ilmariksi, & father called him Ilmari \\
\hline no ehtopoiakseen, & veet boy \\
\hline $\begin{array}{l}\text { nuu pereh nimettömaksi, } \\
\text { eliet vennonioutioksi }\end{array}$ & the other kin, the nameless \\
\hline & \\
\hline Tuli pap & ne to christen him \\
\hline Virokannas kastamaan, & Virokanas to baptise \\
\hline Palvonen pitelemään. & and Palvonen to hold him. \\
\hline Sepä noin sanoiksi virkki: & Now he put this into words: \\
\hline "Ketä tuohon tuotanehe & "Who will be brought here \\
\hline
\end{tabular}




$\begin{array}{ll}\text { Sano vanha Väinamöinen: } & \text { The old Väinämöinen said: } \\ \text { "Poika suolle vietäköö, } & \text { "Carry the boy to a marsh } \\ \text { puulla päähän lyötäköö!!" } & \text { and strike his head with a log!" } \\ \text { [---] } & \text { [---] }\end{array}$

(Kuusi, Bosley, Branch 1977: 281-282).

According to Martti Haavio this song reflects the old, pre-Christian belief that a child must be named after a late relative. In order to call him to life again, one must know who is the father of the child (Haavio 1952, 178-181). In pre-Christian Scandinavia people believed that until a child had not got the name of the deceased person, the soul of the latter could not go from the grave to the otherworld (Kuusi, Bosley, Branch 1977: 550).

The above-mentioned agenda of 1699 also includes a chapter telling what to do with little foundlings: they must be baptised at any rate, unless there is certain proof that this has already been done.

On the ground of runo songs, we may guess that in Estonia, as among Germanic peoples, is was above all the father of the family who decided whether the child's life should be spared or not. This is confirmed by several types of Estonian runo-songs, where the motif of killing a child is represented. Often other members of the family also exert pressure upon the mother.

$\begin{array}{ll}\text { [---] } & \text { [---] } \\ \text { Sai see Jumal minda loonud - } & \text { As soon as God created me } \\ \text { loi mind ema abissa. } & \text { Created me for the help of my mother } \\ \text { Isa hakkas ema vihkamaie: } & \text { Father began to hate my mother: } \\ \text { "Emakene, memmekene, } & \text { Mother, dear mother, } \\ \text { vii sa tütar vesile, } & \text { Take the daughter to the water, } \\ \text { kanna armu allikasse!" } & \text { Bring your love into the well. } \\ \text { [---] } & \end{array}$

(Tedre 1971: 97-98< < Hää).

$\begin{array}{ll}\text { [---] } & \text { Oh God, my God, } \\ \text { Oh Jumal, Jumaluke, } & \text { Why did God create me, } \\ \text { Miks see Jumal minda lõi } & \text { Father had me drowned, } \\ \text { Isa mind käskis uputada } & \text { Brothers had me thrown into the water, } \\ \text { vennad vette visata } & \text { Sisters bade to cast me into waves.[---] } \\ \text { oed aga laska lainetesse!" [---] } & \end{array}$

$($ E $6717(5)<\mathrm{Tln})$.

The fact that baptism was the central point of the rite of passage is also confirmed by several omens and magical acts, the content of which is to influence the child's future towards the desirable. Their great variety and wide distribution call for a separate treatment, therefore I shall illustrate it with but a few examples: 
Before christening one must read the Bible, then the child will be a good reader $\left(\mathrm{E} 8^{\circ} \mathrm{V}, 8\right.$ $(23)<\mathrm{Trt})$.

The child's mouth is washed with milk before christening, then the pre-natal defects will disappear (E $80122(3)<\mathrm{Plv}$ ).

Before baptism some food is placed on the table but not eaten; during baptising the food is on the table, so that the child will suffer no shortage of food in the future (H II 34, 293 (14) < Kuu).

When the child is brought home after baptising, all kinds of tools are handed to him, so that he would make a good workman (E 6693 (12) < Tõs).

Baptismal water was usually thrown on the roof, then the child would be famous; or into an apple tree, then the child would be pretty; but if it was thrown over a girl, she was to become indecent (ERA II 135, 113/4 (8) < Tor).

In pre-Christian times a child was evidently given social status later than in the case of Christian baptism that people tried to have done as soon as they could. Of course, a new-born baby had hope to survive after such symbolic acts as washing after birth or placing it on its mother's breast, but the ultimate recognition came much later. Asko Vilkuna has shown that in Finland it took place with the appearance of the first tooth, which also meant that the child had acquired a guardian spirit (Vilkuna 1959: 32-40). This archaic custom is also manifest in the tradition (which is widely known also in Estonia) of giving the child "tooth money" after baptism. Thus, a new-born baby had to demonstrate its vitality and, in spite of its helplessness, to oppose the negative forces alone, and only after that it was granted the right to stay alive. The following customs connected with the appearance of the baby's first tooth are no doubt of archaic origin:

When the baby is cutting its first tooth, on the very first visit a string of beads is put around the girl's neck, for her teeth to grow strong; a boy is given a knife in his hand (H III 5, 596 $(23)<$ Tor).

When the baby is cutting teeth, a wolf's fang is put into the child's hands or hung around its neck with a string. If there isn't any, a boar's fang will do. If they do so, the child will have good strong teeth (EKS $8^{\circ} 1,944 / 5(22)<$ Vän).

When the baby is cutting its first tooth, a string of beads is hung around its neck; if afterwards the child goes out with a bare neck (i.e. without beads), then in the other world they will hang a dog's tail around its neck in return (H IV 9, 358 (8) < Ris).

Wolf of horse teeth hung around the neck to enhance the growth of teeth were also known among Germans (Boesch 1900: 38) and most certainly the desire to have strong teeth is also very old. But this is obviously still not enough to unravel the real meaning of the practice. With a rite of passage it is important to have an outward sign to mark the changed status of the child. In pre-Christian times it was the first tooth that suggested the child's vitality; but also the string of beads or an amulet hung around the child's neck and the name given to the child. In Christianity only the name remained of these (sometimes also the cross on one's neck), and therefore the witnesses played an 
important role to testify that baptism had indeed taken place. Inviting godparents has usually been explained so, that they are like another couple of parents to the human being who is born again in baptism. It is their duty to see that the child is raised as a proper Christian and to support him or her in the future. But in addition to that, being a witness was also crucial, because there were no external signs to show the changed status of the child. In a relevant chapter of the 1699 manual concerning emergency baptism, there is not a word about godparents, but witnesses are mentioned instead, who could testify for the clergyman that baptism had taken place. The Catholic Agenda Parva from the period of Counter-Reformation in Estonia also stresses in the exhortation to the godparents that they must bear witness to the effected baptism of the child (Agenda Parva 1938: 7677).

The cutting of the first tooth is also coherent with the practice of whisking and washing the child, which was also known among Finns. This is most certainly an archaic, once obligatory magic tradition:

In olden times babies used to say: "When I'm cutting teeth, heat the sauna; if there is no wood, use old worn-out birch-bark shoes that you have found by the roadside (Eesti vanasõnad II: 104-105 < Plv).

When a child is cutting teeth, you must whisk it (in sauna), as old folks have said: "If you have nothing else, put batlets into the stove, but one must whisk (the child)" (Eesti vanasõnad II, 104-105 < Rap).

When a baby is cutting teeth, its mother must see to it that the sauna is heated and the child who is cutting teeth must be whisked in the sauna under the soles of its feet and on its bottom. Its benefit is said to be that the teeth cut more easily (E, StK 39, $283(60)<\mathrm{Khk})$.

The obligatory practice of whisking the child was known all over Estonia as reflected in proverbs, belief accounts and folk legends. Its most usual explanation has been the facilitation of cutting teeth.

Ritual washing and perhaps also whisking are customs that have parallels with the other two crucial rites of passage in a human life. Their juxtaposition is important, among other things, in understanding the popular ideas connected with baptism. Washing the dead body was a well-known practice in Estonia and sometimes a whisk was used. In connection with ritual washing and on the background of other central rites of passage the practice of putting a whisk as an essential item into the grave becomes also more comprehensible. It is typical, however, that the passage to the other world required not only washing the dead body, but, according to the belief, his soul also had to be purified:

When a person is dying, put a glass of pure water near him. Then you can see water stir at the very moment of death; his soul washes himself before he leaves (ERA II 12, 419/20 (56) < Sim).

It has occurred in a few cases that before dying a bowl of water and a towel have been placed on the window, and namely for the soul of the dying person. People believe that a soul passes away through the window. He washes himself with the water and dries with the towel. So he leaves his sinful body (ERM 164, $9(11)<\mathrm{MMg})$. 
Whether or not the ritual whisking of the bride (and bridegroom) in the sauna on the eve of the wedding has ever been a general practice in Estonia, is more open to questions. There are a few reports of whisking the bride before wedding, but this does not seem to have any ritual connotation. According to an exceptional written record from the parish of Vigala, the bride and the bridegroom were whisked together "to be quite clean when they enter into their new life" (E $8^{\circ}$ XII, 44 (125)). In the Eastern part of Estonia, however, whisking was known as a wedding joke. The young couple was whisked on the stove or on a wooden platform built of sledges, occasionally also on a stack of wood or on the actual sauna platform.

When people had eaten, they brought in two sledges. Sledges were put atop of each other and a chair was placed on them. Now the bridegroom with the bride sat on the chair together, and groomsmen whisked them with fresh whisks. After the bridal couple had descended from the chair, guests went one by one to get whisked. Each of them had to leave a handful of silver coins on the chair in return for whisking (Äks) (Tedre 1973: 102).

It is possible that the basis of such a joke was an earlier custom that was taken quite seriously.

It is also significant that according to Ferdinand Johann Wiedemann, after the wedding people brought water for the young couple to wash their faces; and they sprinkled each other with it. This was believed to ensure long cohabitation and patience (Wiedemann 1876: 318). Whisking the bride in the sauna has been widespread among Finns, Karelians, and Vepsians (Ojajärvi 1959). The ritual background of the custom is especially conspicuous among the Votes who used to sing special sauna songs on the occasion (Ariste 1960: 52). It is hardly believable that the practice could be explained with Russian influence only, although this must also have been present (Shlygina 1982). That the custom could have been known in Estonia is confirmed by some runos. One might assume that the popular song type "Dirty woman" ("Must naine") dates from the times when the tradition of ceremonial washing and whisking of the bride began to fall into oblivion and its remission was perceived as a deviation from the standard. The following verses have been taken down in Kuusalu, whereas a remark has been added that the song has also been sung at wedding and that it has been performed by the bride's mother:

\begin{tabular}{|c|c|}
\hline $\begin{array}{l}\text { Ei mina suota sauna läinud, } \\
\text { asjata astunud lavale - }\end{array}$ & $\begin{array}{l}\text { I did not go to sauna just for fun } \\
\text { Nor stepped on the sauna platform to no purpose: }\end{array}$ \\
\hline ma sain pojad p & I got sons so roly-poly \\
\hline ja toin tüttäred tümikäd - & And delivered chubby daughters; \\
\hline minijäd sain mielelised & I got daughters-in-law to my liking \\
\hline väimehed viel paremad & And even better sons-in-law. \\
\hline
\end{tabular}

(Vana kannel III 1938: 192).

It may well be that this song speaks about giving birth in the sauna, but one cannot exclude the probability of the song reflecting a former idea that the (pre-nuptial?) ritual washing in the sauna magically increases fertility and guarantees luck for the whole life. It is quite evident that such a magical, purificatory and sanctifying washing and whisking was once of crucial importance when one had to do with the passage of a human being from one status into another (see also Eisen 1932, 61-65). So this archaic tradition became connected with baptism and here we can observe the syncretism of heathen tradition and Christianity: 
In olden times there was baby sauna, when they came back from church and it was the last day of the baptism celebration ('joodud'). Mother went to the sauna with the baby and then others were also told to go and they gave "tooth pennies" (AES 204, 37/8 < Püh).

A common merry sauna-going and whisking has been told by J. B. Holzmayer, who also refers to an earlier published relevant observation of J. W. L. von Luce among the inhabitants of Saaremaa (Holzmayer 1873: 102). The same custom of washing oneself in sauna on the next day after baptism has been touched upon by F. J. Wiedemann (op. cit. p. 308; see also: Vana kannel V 1985: 92-95). That the connection between baptism and whisking in sauna could have been widely known in Estonia seems to be reflected in some runos. A rare South Estonian christening song includes the following verses:

$\begin{array}{ll}\text { [---] } & \text { [---] } \\ \text { Tuu siia tuhkuraha, , } & \text { Bring here the labour money } \\ \text { viä siiä v i h } \text { r a ha } & \text { Fetch the whisking money } \\ \text { saada siiä s a n } \text { n a r a ha a } & \text { Send here the sauna money } \\ \text { lase siiä latseraha } & \text { Hand in the baby money } \\ \text { anna siiä hambaraha! } & \text { Give me the tooth money } \\ \text { [---] } & \text { [---] }\end{array}$

(Tedre 1972: $944<$ San).

Several other runos reflect ritual whisking and washing of the baby. The whole importance of the correct performance of the transition rite becomes evident, since, according to the belief, its cancellation or a careless attitude towards it could spoil the whole future life, making the person in concern miserable and unhappy. It seems that this is the interpretation which enables us to understand the following passages from runos:

$\begin{array}{ll}\text { Mistes meida kurvas loodu, } & \text { Why were we created so sad } \\ \text { kurva loodu, leinä loodu? } & \text { Created so sad and miserable? } \\ \text { See om ollu kurva sanna, } & \text { This was a sad sauna } \\ \text { kus o meida vihutetu; } & \text { Where we were whisked } \\ \text { see om ollu leinäläte, } & \text { This was a mourning spring } \\ \text { kust o meile vetta toodu; } & \text { From where water was brought for us } \\ \text { see o ollu leinäkaske, } & \text { This was a weeping birch } \\ \text { kust o meile vihta toodu; } & \text { From where the whisks were brought } \\ \text { see o ollu kurva kuuske, } & \text { This was a quite miserable spruce } \\ \text { kust o sannapuida toodu. } & \text { That gave firewood for the sauna } \\ \text { [---] } & \text { [---] }\end{array}$

(Tedre 1970: $319<$ Krk). 


\begin{tabular}{|c|c|}
\hline [---] & {$[---]$} \\
\hline Emäkene, memmekene, & Mother, oh Mother \\
\hline ee põle minugi süidi, & I am not to be blame \\
\hline & narried to a serf \\
\hline asupois & in up to wed a vassal! \\
\hline Viisid sauna vihtlema, & You took me to sauna to whisk me \\
\hline vihtsid sellele vihale, & You whisked me with the whisk, \\
\hline ebile, & hed me with the \\
\hline miska enne orjad pesnud & 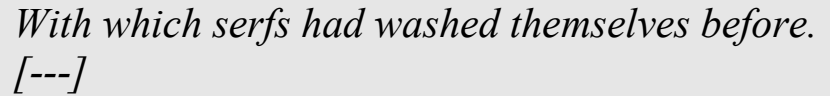 \\
\hline
\end{tabular}

(Tedre 1970: 388-389< KJn).

(Tedre 1970: $318<\mathrm{Kad})$.

It is a parallel to be emphasised that the same motif shows up on Ukrainian folk songs as well. There the unhappy singer turns to his/her mother, complaining: "Didn't you bath me when I was young, did you curse me to be unhappy?" (Kostomarov 1905: 498). That it is not Christian baptism that has been meant is evident from the fact that it speaks about washing the child in the steep of different herbs.

The next reports, however, reflect evidently the survival on heathenish washing ritual in the connection with Christian baptism. Here a belief is expressed that the water for washing must be prepared to ensure sanctifying power.

Of particular importance was the act of washing, and even the preparation of water for washing, before baptising a child. Several pieces of coal were collected into the water, silver was scraped from coins and gold from the parents' rings. All this was done to make the child receptive to the Word of God that was soon to be given to it, and secondly, to season the child for the hardships of life. This washing water was also made somewhat cool. After washing the baby, its father had to wash his face in the water (E 80281/2 $(7)<\mathrm{Hel})$.

In a family in Soosalu people used to put a smoked ring of a broom, birch twigs, a sliver of a stake, a pig jaw-bone and pig hairs into a bowl of water before baptism. After baptism these stood at the foot of the cradle for some time (ERA II 5, $307<\mathrm{PJg}$ ). 
After baptism the baby is washed with baptismal water, then the child will be healthy and not affected by diseases. Also, in some places this water is kept so that it can be used as a medicine afterwards. [---] (H I 2, 651 (11) < Vas).

Before dressing, the child is washed with water mixed with some honey. A girl's wash water was thrown on the horse's feet when they sat into the carriage with the child and set off to church, meaning that so she would get married soon. The same is done with a boy's wash water: then the child will be strong (Grünthal 1924: 444-5 < Tapa).

A child (a girl) was seen to be washed with sweet milk before baptism in Veriora. Why this was done is not known (ERA II 36, $94(42)<$ Plv).

Perhaps the last report throws some light on the motif "Our Bride (Bride-groom) Has Been Washed with Milk", which is widely known in wedding songs of Western Estonia. This motif may reflect a once actual magical purification by washing, connected with a rite of passage. Some material for reflection is also offered by the proverb "Not everybody is washed with the same water", translated by A. Thor-Helle in his grammar published in 1732 as "viel Köpfe, viel Sinne". The other two main redactions of the same proverb are, however, "is not whisked" and "is not baptised" (Eesti vanasõnad I, 410-411). This proves that the semantic fields of these words are partially overlapping. This is possibly another reflection of the idea that baptismal water and the rite of washing have an influence on the child's future and character.

It is noteworthy that F. J. Wiedemann translates the old saying "Wine has been birched" into German as "der Wein ist getauft" (Wiedemann 1923: 1373-4). It seems that in the archaic rite of passage magical whisking or beating with birch twigs (that may be considered analogous actions) was as important as washing. According to Lauri Kettunen's etymology a synonym for 'baptism' varrud - is a conjugate of the noun varb - 'twig, rod', and of the verb varvutama - 'to rod, to sprinkle (with twigs)' (Kettunen 1920: 56-60; Talve 1959). Only when this background is taken into consideration can we see the significance of the following report:

When a child is brought home after baptism, it is whipped at the door or by the fireplace, then it should always be a good child (E 40760 (2) < Ans).

Such twigging to secure the child's health and welfare is widely known in popular tradition. One might think, for instance, of the practice of beating with catkins on Palm Sunday (Hiiemäe 1981: 140-142). Rods were also carried by Martinmas minstrel-beggars, who used to beat members of the household with these, saying: "Raw and healthy." Perhaps Santa Claus also carries a now useless rod as a reflection of an ancient belief that it has a healing effect.

In connection with the above considerations, there arises a problem of how one should actually understand the old sources speaking about the heretical practice of washing away baptismal water, which has occurred on the territory of Estonia.

For example, the resolutions of the diet (landtag) in Valga in 1422 demanded that Estonians "have their children baptised after the ways of the church within a month from their birth". And also, that "no one should elude baptism or wash it away on pain of death". At Valmiera diet, which took place in 1504, the resolutions of the Valga diet were pronounced again (Vahemetsa 1961: 161-162).

Bearing in mind the ancient customs of the Estonians, one cannot exclude the possibility of it being a mere groundless distrust of some too vigilant clerics towards the people, suspecting them of being heathens more than there was reason to. It is clear that baptism took over the functions of heathen 
rites and probably it had to be combined with an additional purification rite which by no means suggested washing away the baptismal water. It is open to question whether, according to magical thought, it is possible at all to entirely wash away the baptismal water (anyway, it would require an extraordinary counter-magic).

Very many customs related to baptismal water confirm that it was not seen as an ordinary liquid that was poured on you and that afterwards could be washed away tracelessly; it was a real miracleworking substance. One cannot really believe that the Estonian peasants, who were the bearers of religious traditions, could have a similar attitude towards it as has the modern atheist and rationalist mind to whom magical thought is hopelessly unintelligible. In baptism as a ritual act of washing away the original sin ("das Bad der Wiedergeburt") and in the ritual act of washing and whisking in sauna we can simply see a blending of two planes: a Christian and a heathen one. Here we can also notice features common with other peoples: for instance, the Germanic tribes were aware of the practice of sanctifying the child with water as a necessary ceremony in recognising the child as a member of the tribe already before christianisation (Vries 1956: 179-80). Several sayings about raining (and thunder) and the sun shining at the same time ("the Evil One is washing children", "the devil's child is being baptised", "gypsy sauna", etc.) (Kuusi 1957; Hennoste 1984) suggest the popular ideas discussed above. It is possible that in pre-Christian times such washing rites took place in the open air, whereby heavenly waters and especially thunderstorm could indeed be ascribed a special power. From among natural waters, some springs have been especially valued, according to a number of reports. For example, even quite recently people used to bathe in a rivulet near St. John's stone in the village of Meeksi, Seto territory, on St. John's Day; they even took "the water from the holy spring" home with them (Wiedemann 1876: 415). The attitude of the clergymen towards these heathenish acts of washing has most certainly not been positive and it is probably for this reason that these were ultimately transferred to people's homes and especially to the sauna where the eyes of Catholic priests and Lutheran parsons could not penetrate.

Of course, the reports of Henric's Chronicles of Livonia about the Estonians washing away the baptismal water can hardly be explained in the same way. In the 13th century forceful christening could indeed be interpreted as surrendering to a foreign power and people tried to get rid of it. But in the context of much later times, one cannot exclude the possibility of it being a misunderstanding that has been a conventional truth already since the Middle Ages. Anyway, it is evident that the relations between Christianity and folk belief in Estonia in different periods is a topic that requires a many-sided approach. The syncretism of heathen and Christian features that one so often comes across shows that conversion into Christianity was quite smooth, rather than abrupt. It is clear even from a slightest inquiry that Estonian peasants were far from being "heathens of principle" who would avoid the church. They were open and receptive to Christian influences, but at the same time they relied on the existing religious ideas and often understood the new religion in their own way. According to the Christian view, baptism is not a mere formality that makes a difference between a Christian and a heathen - being a sacrament, it has the power to sanctify, which binds the former heathen to God and renders him under the heavenly protection. It is baptism that makes a Christian.

translated by Kai Vassiljeva. 


\section{References:}

Aarne, A. 1918. Estnische Märchen- und Sagenvarianten. FFC 25. Hamina.

Agenda 1951 = Eesti Evangeeliumi Luteri Usu Kiriku Agenda. Stockholm.

Agenda Parva 1938 = Agenda Parva Brunsbergae MDCXXII. Tartu.

Aly, W. 1934/35. Name. Handwörterbuch des deutschen Aberglaubens VI. Berlin und Leipzig, pp. 950-962.

Ariste, P. 1960. Vadjalaste laule. ENSV TA Emakeele Seltsi toimetised 3. Tallinn.

Boesch, H. 1900. Kinderleben in der deutschen Vergangenheit. Leipzig.

Dunte, M. L. 1643. Decisiones Mille et Sex Casuum Conscientiae \& Diversis Theologorum Scriptis collectae, contractae, et in brevitatem redactae, ac luxta ordinem Locorum Theologicorum positae.

Lübeck.

Eesti vanasõnad I - IV. Toim. A. Krikmann, I. Sarv. Tallinn, 1980 - 1988.

Eesti-Ma-Rahwa Koddo- ja Kirko-Ramat. 1793. Tallinn.

Eisen, M. J. 1932. Saun ja vihtlemine. Eesti Rahva Muuseumi aastaraamat 8. Tartu.

Grünthal, J. 1924. Eesti rahvameditsiin... Eesti Kirjandus XVIII, pp. 299-308, 334-347, 386-395, 443-453, 475-491.

Haavio, M. 1952. Väinämöinen, Eternal Sage. FFC 144. Helsinki.

Heitmüller, W. 1903. "Im Namen Jesu." Göttingen.

Hennoste, M. 1984. Nõiad vihtlevad. Keel ja Kirjandus nr 3, pp. 163-167.

Hiiemäe, M. 1981. Eesti rahvakalender II. Tallinn.

Holzmayer, J. B. 1873. Osiliana II. Verhandlungen der Gelehrten Estnischen Gesellschaft zu

Dorpat. VII - 2. Dorpat.

Honko, L. 1964. Siirtymäriitit. Scripta Ethnologica 17. Turku.

Karjalainen K. F. 1918. Jugralaisten uskonto. Suomensuvun uskonnot III. Porvoo.

Kässi-Ramat 1699 = Kässi-Ramat/ Kumma sisse on kokkopantut Kuida Jummalateenistust /

Christlikko kombede nink kirko-Wiside ka meie Ma Koggoduste sees peap peetama nink techtama.

Sädut Tokolmi linnas ue Kirko-Sädust mööda selle 1693 Aastal. Tallinn.

Kettunen, L. 1920. Eesti varrud 'Kindtaufe, Taufschmaus'. Eesti Kirjandus XIV, pp. 56-60.

Kostomarov, N.I. 1905. Istoricheskoye znacheniye yuzhno-russkogo narodnago pessennago

tvorchestva. Sobraniye sochinenii VIII: tom 21. Sankt Peterburg.

Krushelnitski, J. 1986. Mis on teie nimi? "Edasi", 11. 02. 1986.

Kuusi, M. 1957. Regen bei Sonnenschein. Zur Weltgeschichte einer Redensart. FFC 171. Helsinki.

Kuusi, M. 1963. Suomen Kirjallisuus I. Kirjoittamaton kirjallisuus. Helsinki.

Kuusi, M.; Bosley, K.; Branch, M. 1977. Finnish Folk Poetry. Epic. An Anthology in Finnish and English. Helsinki.

Lindow, J. 1978. Rites of Passage in Scandinavian Legends. Fabula. Band 19, Heft 1/2. New York, Berlin, pp. 40-61.

Loorits, O. 1949. Grundzüge des estnischen Volksglaubens I. Lund.

Lühhikene Tarto-Ma-Kele Palwusse Ramat. Riga, 1790.

Ojajärvi, A. 1959. Morsiussauna. Kalevalaseuran Vuosikirja 39. Helsinki, pp. 294-313.

Palli, H. 1961. Mida kõnelevad isikunimed eestlaste usust XIII - XVI sajandil. Religiooni ja ateismi ajaloost Eestis II. Tallinn, pp. 108-127.

Pentikäinen, J. 1968. The Nordic Dead-Child Tradition. Nordic Dead-Child Beings. A Study in

Comparative Religion. FFC 202. Helsinki.

Pentikäinen, J. 1969. The Dead without Status. Temenos 4. Helsinki, pp. 92-102.

Realencyklopädie für protestantnische Theologie und Kirche 19. Leipzig, 1907. 
Saareste, A. 1921. Mitmesugused riismed. Eesti Kirjandus XV, pp. 392-394, 422-425.

Simon, M. 1991. Der Pate als Namengeber. Rheinisch-westfälische Zeitschrift für Volkskunde. 36 Jahrgang, pp. 215-227.

Shlygina, N. 1982. Vene mõjusid vadja pulmakombestikus. Läänemeresoomlaste etnokultuuri küsimusi. Tallinn, pp. 36-40.

Talitusraamat 1940 = Eesti Apostliku-Õigeusu Kiriku Talitusraaamat. Tallinn.

Talve, I. 1959. Suomen varpaiset ja sen taustaa. Scripta Ethnologica 2. Turku.

Tedre, Ü. 1969-1972. Eesti rahvalaulud. Antoloogia. I - III. Tallinn.

Tedre, Ü. 1973. Eesti pulmad. Tallinn.

Uus Lauluraamat. Väikene lisata väljaanne. Jurjew, 1901.

Vahemetsa, A. 1961. Eestlaste võitlusest ristiusu vastu XII - XVI sajandil. Religiooni ja ateismi ajaloost Eestis II. Tallinn, pp. 150-172.

Vana kannel III. Kuusalu vanad rahvalaulud I. Toim. H. Tampere. Tallinn, 1938.

Vana kannel V. Mustjala regilaulud. Toim. H. Tampere, E. Tampere. Tallinn, 1985.

Viires, A. 1989. Kui vana on vanapagan? Keel ja Kirjandus nr 9, pp. 542-551.

Vilkuna, A. 1959. Die Ausrüstung des Menschen für seinen Lebensweg. FFC 179. Helsinki.

Vries, J. de. 1956. Altgermanische Religionsgeschichte I. Berlin.

Wiedemann, F. J. 1876. Aus dem inneren und äusseren Leben der Ehsten. St. Petersburg.

Wiedemann, F. J. 1923. Eesti-Saksa Sõnaraamat. Tartu.

Wuttke, A. 1925. Der deutsche Volksaberglaube der Gegenwart. Leipzig. 